\title{
Effects of fruiting spur thinning on fruit quality and vegetative growth of sweet cherry (Prunus avium)
}

\author{
Marlene Ayala, and María P. Andrade \\ Departamento de Fruticultura y Enología, Facultad de Agronomía e Ingeniería Forestal, Pontificia \\ Universidad Católica de Chile, Casilla 306-22, Santiago, Chile.
}

\begin{abstract}
M. Ayala, and M.P. Andrade. 2009. Effects of fruiting spur thinning on fruit quality and vegetative growth of sweet cherry (Prunus avium). Cien. Inv. Agr. 36(3):443-450. High density sweet cherry (Prunus avium) orchards using highly productive cultivars and dwarfing rootstocks usually require crop load regulation to achieve high quality fruit. Among the strategies used to reduce crop load in highly productive combinations, fruiting spur thinning (FST, spur extinction) before budbreak has been suggested to be an effective way to improve fruit size. Currently, there is little information about the effect of spur thinning on sweet cherry orchards using self-fertile cultivars grafted on vigorous rootstocks. For this reason, the objective of the present study was to evaluate the effects of manual FST on fruit quality and vegetative growth of the cultivar 'Lapins' grafted on the rootstock 'Mazzard F-12/1 ' with 0, 50 and 75\% spur removal. Spur removal was carried out 28 days before full bloom (August 23). FST had no beneficial effects on fruit size, total soluble solids or fruit weight. However, there were significant differences in the foliar development of current season growth and fruiting and nonfruiting spurs. Although the leaf area to fruit ratio was high in all treatments, this parameter increased with the removal of 50 and $75 \%$ of fruiting spurs. Fruit quality did not increase, suggesting a possible sink limitation of Lapins ' grafted on 'Mazzard F-12/1 ' or the presence of an alternative vegetative sink that is stronger than the fruit. However, further research is needed to clarify this point.
\end{abstract}

Key words: Crop load regulation, fruit growth, fruit quality, leaf area, leaf to fruit ratio, Prunus avium, shoot growth, spur extinction.

\section{Introduction}

In Chile, there still exist traditional low density sweet cherry orchards (around 278 treeha $^{-1}$ ) using vigorous rootstocks. However, many high density orchards have been established in the

Received 12 January 2009. Accepted 29 May 2009. Corresponding author: mayalaz@uc.cl last decade $\left(\geq 667\right.$ treeha $\left.^{-1}\right)$ by using more productive cultivar combinations grafted on medium- and low-vigor rootstocks (Claverie and Joublan, 2004; Lemus, 2005; Ayala, 2008). These modern combinations are more precocious and produce higher yields (Lang, 1998; Whiting et al., 2005). Nevertheless, a limitation of this tree type is the need for crop load regulation to avoid a deterioration in final fruit quality (Whiting et al., 2005; Whiting and Ophardt, 2005) and premature aging of the orchard due 
to a gradual reduction in the leaf area/fruit ratio (LA/F). An intermediate situation is the adoption of self-compatible cultivars grafted on vigorous rootstocks, which allows for a high yield per tree and reduces the risk of excessive crop load and tree weakness when full production is reached.

In sweet cherry, carbohydrates partitioned to fruit are mainly provided by leaves of reproductive and vegetative spurs and current season shoots (Ayala, 2004). One way to evaluate the relationship between fruit quality and the balance between supply and demand in these species is through the LA/F ratio (Whiting, 2005). The sensitivity of sweet cherry to the LA/F ratio becomes evident in highly productive and/ or low-vigor combinations. In these cases, the contribution of photoassimilates by leaves becomes especially relevant because smaller and precocious trees produce a higher crop load that competes with vegetative growth during the growing season. This necessarily involves the adjustment of the LA/F ratio to avoid an imbalance between vegetative and reproductive sinks, which compete for carbohydrates during the period of fruit development (Ayala, 2004).

One way to keep the tree in balance and ensure an optimal LA/F ratio in highly-productive sweet cherry combinations is through crop load regulation. Several strategies have been proposed in recent years, including pruning (Long, 2002), fruiting spur thinning (FST) (Claverie and Lauri, 2005a), fruit thinning (Podestá et al., 2005) and flower thinning (Whiting and Ophardt, 2005).

FST (spur extinction) is one practice that is suggested to be an effective alternative to regulate crop load in commercial orchards (Claverie and Lauri, 2005a; Claverie and Lauri, 2005b; Long, 2002). The method consists of manually and selectively removing fruiting spurs (FS) and the lower portions of branches older than one year. This is done in winter or before bloom (Claverie and Lauri, 2005a; Guerendiain, 2006) in order to promote uniform fruit distribution by indirectly decreasing the fruit number per branch. The physiological effect of FST is to produce better photoassimilate distribution among a lower number of fruits, allowing for a balance between vegetative and reproductive growth (Claverie and Lauri, 2005a).

Claverie and Lauri (2005a) reported that FST increased fruit size in the low-vigor combination 'Summit'/'Tabel ${ }^{\circledR}$ Edabriz', and this effect was greater in the second year. In addition, FST improved fruit color and moved the date of the harvest forward. On the other hand, studies by Whiting and Ophardt (2005) on the low-vigor combinations 'Bing'/'Gisela ${ }^{\circledR} 5^{\text {‘ }}$ and 'Bing'/'Gisela®6' failed to demonstrate effects of FST on fruit size and yield over a two-year study period, possibly due to removal of LA by FS elimination.

There is little information in Chile on the effects of FST on sweet cherry fruit quality and seasonal vegetative growth in combinations of self-compatible cultivars grafted on vigorous rootstocks. In theory, FST should positively influence fruit quality and foliar development in the 'Lapins'/'Mazzard F-12/1' sweet cherry combination. Therefore, the objective of this study was to determine the effects of three FST intensities on fruit quality and vegetative growth in sweet cherry trees.

\section{Materials and methods}

\section{Location}

This study was carried out in 2006 in a sweet cherry orchard of the 'Lapins'/'Mazzard F-12/1' combination planted in 1996 and located in San Francisco de Mostazal, VI Region, Chile (33 $59^{\circ} \mathrm{S} ; 7^{\circ} 43^{\prime} \mathrm{W}$ ). The orchard was trained in a central axis with solaxe, planted at $5.0 \times 2.5 \mathrm{~m}$ and irrigated by aspersion. The climate of the area presents moderate rains in winter with annual average rainfall varying between 500 and $1000 \mathrm{~mm}$. The annual thermal regime presents average maximum and minimum temperatures of $29^{\circ} \mathrm{C}$ (January) and of $2.8^{\circ} \mathrm{C}$ (July), respectively. The frost-free period is between November and March, and the dry period is between November and April. The soil type is a clay loam with low drainage capacity. 


\section{Treatments}

In August 2006, 129 homogeneous branches (one branch per tree) were characterized with respect to age, length, diameter, and the number of reproductive spurs that developed over three seasons. In each of these branches, the fruit segment (growth 2003-4, 2004-5 and 2005-6) was divided into three sections corresponding to three fruit positions of equal length (Figure 1): upper section (US), middle section (MS) and bottom section (BS). Twenty-eight days before bloom (DFB, August 23 ${ }^{\text {rd }}$ ), FST was conducted manually at three intensities: 0,50 and $75 \%$ of the total number of FSs.

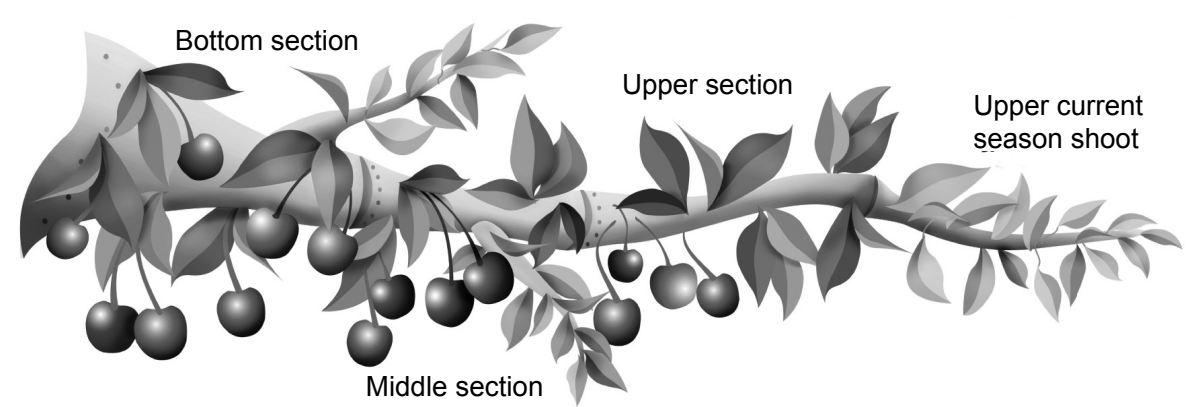

Figure 1. Sweet cherry branch diagram showing three growth seasons (2003-2004; 2004-2005; 2005-2006) and shoots (growth 2006-2007). Fruit wood was segmented into three parts: upper, middle and bottom sections.

\section{Evaluations}

Thirty branches (10 branches per treatment) were selected from among the characterized branches for weekly field measurements. These branches were evaluated every seven days until harvest for the following parameters: a. ventral diameter and individual fruit cheeks ( $\mathrm{n}=$ 5) in US, MS and BS; b. length of upper current season shoot (UCSS); c. number of mature leaves (ML) and immature leaves (IL) on the UCSS and d. basal branch diameter. Growth measurements of branches began at full bloom ( 0 days after full bloom $=0$ DAFB; 20 September) and continued to commercial harvest (77 DAFB, 06 December). The criterion of fruit harvest was based on color (mahogany red) and average total soluble solids content, or TSSC $(\geq 18 \%)$.

From the remaining branches, nine units were removed at random (three branches per treatment) each week (11 continuous weeks) for laboratory evaluation. These branches were measured for the following parameters: a. Fresh fruit weight $(\mathrm{FW})$ in US, MS and $\mathrm{BS}(\mathrm{n}=5)$, b. Leaf area (LA) of UCSS, non-fruiting spur
(NFS) and FS and, c. Fruit TSSC in US, MS and $\mathrm{BS}$ at the date of the harvest $(\mathrm{n}=5)$.

LA was quantified with a leaf area meter (Model LI-3100, LI-COR Biosciences Inc., Nebraska, USA). TSSC per fruit was measured with a manual refractometer with automatic temperature compensation of $0-32 \%$ (Refractec, Hong Kong, China). Fruit diameter was measured with a $0.00-200.00 \mathrm{~mm}$ digital caliper (Digimess, Buenos Aires, Argentina).

\section{Design and statistical analysis}

A completely randomized experimental design was established for FST distribution treatments for each experimental unit, which was defined as a fruiting-branch. For weekly field measurements, ten repetitions per treatment were measured. Measurements in the laboratory (three repetitions per treatment) were taken each week. Analyses of variance were conducted using the Linear Regression Model (LRM). The statistical analysis was done with SAS ${ }^{8} 9.1$ (SAS Institute Inc., Cary, NC, USA). Means were compared by the Tukey minimum significant differences test $(\mathrm{p} \leq 0.05)$. 


\section{Results and discussion}

\section{Fruiting- spur thinning effect on fruit quality}

FST did not significantly affect fruit quality at the date of the harvest $(p \geq 0.05$, Table 1$)$. Average fruit diameter for all FST intensities was approximately $26 \mathrm{~mm}$. Nor was a significant FST effect observed on fruit diameter in sections evaluated within fruiting segments ( $\mathrm{p} \geq 0.05$, Table 2$)$.

Table 1. Fruiting spur thinning effects on fruit quality of the sweet cherry (Prunus avium) combination 'Lapins'/'Mazzard F-12/1' at the date of harvest (77 DAFB on December $6^{\text {th }}, 2006$ ).

\begin{tabular}{llll}
\hline $\begin{array}{l}\text { Fruiting } \\
\text { spur } \\
\text { thinning } \\
\%\end{array}$ & $\begin{array}{l}\text { Size } \\
\mathrm{mm}\end{array}$ & $\begin{array}{l}\text { Soluble solids } \\
\%\end{array}$ & $\begin{array}{l}\text { Fresh weight } \\
\mathrm{g}\end{array}$ \\
\hline 0 & $26.2 \pm 0.3 \mathrm{a}^{1}$ & $20.0 \pm 0.3 \mathrm{a}^{1}$ & $11.4 \pm 0.4 \mathrm{a}^{1}$ \\
50 & $26.5 \pm 0.7 \mathrm{a}$ & $20.4 \pm 0.3 \mathrm{a}$ & $11.0 \pm 0.5 \mathrm{a}$ \\
75 & $26.0 \pm 0.7 \mathrm{a}$ & $21.0 \pm 0.4 \mathrm{a}$ & $10.0 \pm 0.3 \mathrm{a}$ \\
p-value & 0.7820 & 0.6377 & 0.0506 \\
\hline
\end{tabular}

${ }^{1}$ Averages followed by equal letters within a column do not differ statistically according to Tukey's comparison test $(\mathrm{p}=0.05)$.

Table 2. Fruit spur thinning effects on fruit size and total soluble solid on upper, middle, and bottom sections of three-year-old branches in the sweet cherry (Prunus avium) combination 'Lapins'/'Mazzard F-12/1' at the date of harvest ( 77 days after full bloom on December $6^{\text {th }}, 2006$ ).

\begin{tabular}{|c|c|c|c|}
\hline $\begin{array}{l}\text { Fruiting } \\
\text { spur } \\
\text { thinning } \\
\%\end{array}$ & $\begin{array}{l}\text { Upper } \\
\text { section }\end{array}$ & $\begin{array}{l}\text { Middle } \\
\text { section }\end{array}$ & $\begin{array}{l}\text { Bottom } \\
\text { section }\end{array}$ \\
\hline & \multicolumn{3}{|c|}{ Fruit size, $\mathrm{mm}$} \\
\hline 0 & $\begin{array}{l}25.7 \pm \\
0.6 \mathrm{a}^{1}\end{array}$ & $26.7 \pm 0.4 \mathrm{a}^{1}$ & $26.2 \pm 1.0 \mathrm{a}^{1}$ \\
\hline 50 & $\begin{array}{l}25.4 \pm \\
0.3 \mathrm{a}\end{array}$ & $27.7 \pm 0.0 \mathrm{a}$ & $26.4 \pm 0.5 \mathrm{a}$ \\
\hline 75 & $\begin{array}{l}26.2 \pm \\
0.5 \mathrm{a}\end{array}$ & $25.0 \pm 0.5 \mathrm{a}$ & $26.8 \pm 0.4 \mathrm{a}$ \\
\hline \multirow[t]{2}{*}{ p-value } & $\mathrm{p}=0.7971$ & $\mathrm{p}=0.6211$ & $\mathrm{p}=0.8041$ \\
\hline & & otal soluble solids, & $\%$ \\
\hline 0 & $\begin{array}{l}20.6 \pm \\
0.4 \mathrm{a}^{1}\end{array}$ & $20.0 \pm 0.3 a b^{1}$ & $19.3 \pm 0.2 b^{1}$ \\
\hline 50 & $\begin{array}{l}20.6 \pm \\
0.6 \mathrm{a}\end{array}$ & $19.2 \pm 0.2 b$ & $21.5 \pm 0.2 \mathrm{a}$ \\
\hline 75 & $\begin{array}{l}21.0 \pm \\
0.3 \mathrm{a}\end{array}$ & $20.7 \pm 0.4 a$ & $21.4 \pm 0.4 \mathrm{a}$ \\
\hline p-value & 0.8198 & 0.0247 & 0.0002 \\
\hline
\end{tabular}

${ }^{1}$ Averages followed by equal letters within a column do not differ statistically according to Tukey's comparison test $(\mathrm{p}=0.05)$.
Similar results on FST and fruit quality have been reported in Chile in terms of its low effectiveness for the low-vigor 'Bing '/'Gisela ${ }^{\circledR} 5$ ' combination (Wedeles, 2006). These results differ from those reported by Claverie and Lauri (2005a) and Claverie and Lauri (2005b), both in the 'Summit/'Tabel®Edabriz' combination, where $30 \%$ and $30-50 \%$ FST levels respectively, produced higher fruit size at the day of the harvest.

In this study, the lack of response to FST in fruit quality could be attributable to the cultivar/ rootstock combination used and/or to a natural increase in the LA/F ratio during the 2006-7 season that increased the photoassimilate available for fruit in branches with or without FST. This increase in leaf number per fruit was caused by deficient fruiting set caused by low cold-unit accumulation in the study area ( $\leq 600$ cold units) during the season. Higher photoassimilate availability provided by higher numbers of leaves per fruit could have influenced the lack of response of the combination to the treatments, possibly due to a sink limitation condition (Baysdorfer and Bassham 1985; Layne and Flore, 1985; Roper and Loescher, 1987). According to this theory, fruit quality is limited by internal fruit factors that are not related to photoassimilate supply (Roper and Loescher, 1987). Another explanation is that the combination under study simply has low natural response to FST associated with its ability to reach a balance between fruit load and vegetative vigor during the season.

On the other hand, there were no significant differences regarding TSSC accumulation (approximately 20.5\%) when FST levels were compared at the day of the harvest. There were variations among treatments when comparing fruit from each fruiting segment section $(\mathrm{p} \leq 0.05$, Table 2). Fruit TSSC in the US was similar between treatments, and it was $20.7 \%$ in average. By contrast, fruit in the MS and BS showed significant differences among the treatments.

Fruit in the US showed no significant differences, possibly due to the closer proximity to UCSS leaves and to the NFS (located in oneyear-wood). These two-leaf populations could have contributed sufficient photoassimilates to these fruit once they completed their growth early in the season and could have transformed 
themselves into net exporters favoring TSSC accumulation in all treatments. It was observed that in the BS, the 50 and $75 \%$ FST treatments showed higher TSSC accumulation compared with the $0 \%$ FST treatment. In the MS, a less clear FST effect was observed. Therefore, it is necessary to carry out further studies to unravel the relationships between fruit position on the branch, sink capacity and final fruit quality.

\section{Fruiting spur thinning effect on vegetative growth}

FST significantly affected the LA development of branches ( $p \leq 0.05$; Table 3$)$. The average total leaf area (TLA) in branches with 0 and $50 \%$ FST was similar (around $9178 \mathrm{~cm}^{2} \mathrm{LA}$ ). By contrast, branches with $75 \%$ FST showed $25 \%$ less TLA, mainly due to FS removal and to lower UCSS foliar development (Table 3). The fact that branches with $0 \%$ and $50 \%$ FST showed similar TLA is interesting (Table 3). This was attributed to a higher leaf size in the FSs, NFSs and UCSS (Table 3). It is likely that branches with $50 \%$ FST were able to compensate for the loss of LA by increasing leaf size, which would have compensated for the LA reduction in the FS population and maintained the photoassimilates available for fruiting (Figure 2). Regarding leaf development of the FSs and NFSs, it is noteworthy that branches with 50 and $75 \%$ FST showed larger leaves in comparison to branches with $0 \%$ FST (Table 3).

Table 3. Leaf area and average leaf size per branch section and total leaf area (TLA) per branch for three different fruiting spur thinning levels in the sweet cherry (Prunus avium) combination 'Lapins'/'Mazzard F-12/1' at the date of harvest (77 days after full bloom on December $6^{\text {th }}$, 2006).

\begin{tabular}{|c|c|c|c|c|}
\hline $\begin{array}{l}\text { Fruiting } \\
\text { spur } \\
\text { thinning } \\
\%\end{array}$ & Upper shoot & $\begin{array}{l}\text { Non- } \\
\text { fruiting } \\
\text { section }\end{array}$ & $\begin{array}{l}\text { Fruiting } \\
\text { section }\end{array}$ & $\begin{array}{l}\text { TLA per } \\
\text { branch }\end{array}$ \\
\hline & \multicolumn{4}{|c|}{ Leaf area, $\mathrm{cm}^{2}$} \\
\hline 0 & $\begin{array}{l}846.5 \pm \\
2.1 \mathrm{~b} 1\end{array}$ & $\begin{array}{l}2788.3 \pm \\
52.5 \mathrm{~b} 1\end{array}$ & $\begin{array}{l}5523.9 \pm \\
28.5 \mathrm{a} 1\end{array}$ & $\begin{array}{l}9158.7 \pm \\
61.9 \mathrm{a} 1\end{array}$ \\
\hline 50 & $\begin{array}{l}1007.3 \pm \\
0.5 \mathrm{a}\end{array}$ & $\begin{array}{l}3088.6 \pm \\
28.1 \mathrm{a}\end{array}$ & $\begin{array}{l}5102.3 \pm \\
41.6 \mathrm{~b}\end{array}$ & $\begin{array}{l}9198.2 \pm \\
31.6 \mathrm{a}\end{array}$ \\
\hline 75 & $781.8 \pm 2.5 \mathrm{c}$ & $\begin{array}{l}2972.9 \pm \\
36.7 \mathrm{a}\end{array}$ & $\begin{array}{l}3114.6 \pm \\
22.5 \mathrm{c}\end{array}$ & $\begin{array}{l}6869.3 \pm \\
32.0 \mathrm{~b}\end{array}$ \\
\hline p-value & 0.0001 & 0.0055 & 0.0001 & 0.0115 \\
\hline & \multicolumn{4}{|c|}{ Area per leaf, $\mathrm{cm}^{2}$} \\
\hline 0 & $\begin{array}{l}49.8 \pm 5.4 \\
\text { b } 1\end{array}$ & $33.9 \pm 1.5 b$ & $\begin{array}{l}48.2 \pm \\
2.5 \mathrm{~b}\end{array}$ & \\
\hline 50 & $60.7 \pm 6.5 \mathrm{a}$ & $43.3 \pm 1.1 \mathrm{a}$ & $\begin{array}{l}61.9 \pm \\
0.4 \mathrm{a}\end{array}$ & \\
\hline 75 & $48.5 \pm 3.6 \mathrm{~b}$ & $41.9 \pm 2.8 \mathrm{a}$ & $\begin{array}{l}55.7 \pm \\
3.7 \mathrm{a}\end{array}$ & \\
\hline p-value & 0.0062 & 0.0019 & 0.0018 & \\
\hline
\end{tabular}

${ }^{1}$ Averages followed by equal letters within a column do not differ statistically according to Tukey's comparison test $(p=0.05)$.

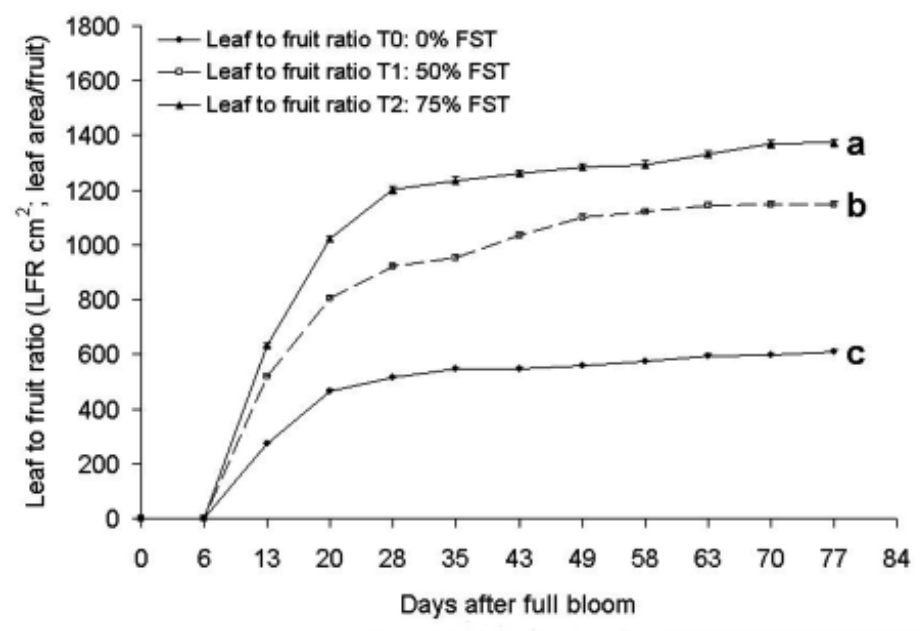

Figure 2. Change in leaf area to fruit ratio (LFR; leaf area $\mathrm{cm}^{2} /$ fruit) in three-year-old sweet cherry (Prunus avium) of the combination 'Lapins'/'Mazzard F-12/1' for three levels of fruiting spur thinning.

Different letters indicate significant differences at the date of the harvest (Tukey test; $n=10 ; p<0.0001$ ). 
Analysis of the upper shoots revealed that branches with 50\% FST showed the highest LA per shoot compared with the other treatments, which was attributed to a higher leaf size (approximately $18 \%$ more LA than in $0 \%$ FST; Table 3). This might be explained by a change in the relative competence of fruit and shoots due to the reduction of fruit number on branches, which could have improved LA development. The opposite was observed in branches with $75 \%$ FST, which showed shoots with lower LA. In this treatment, the strong removal of leaves in FSs possibly resulted in an exaggerated loss of the source and availability of photoassimilate for promoting UCSS development, decreasing the leaf size (Table 3).

On the other hand, a significant FST effect was not observed on UCSS length or final leaf number counted at the day of the harvest (Table 4). Thus, leaf size seems to be the vegetative parameter most sensitive to FST in the UCSS.

Table 4. Fruiting spur thinning effects on sweet cherry (Prunus avium) shoot length and mature leaf number on three-year-old branches of the combination 'Lapins'/'Mazzard F-12/1' at the date of harvest (77 days after full bloom on December $6^{\text {th }}, 2006$ ).

\begin{tabular}{lll}
\hline $\begin{array}{l}\text { Fruiting spur thinning } \\
\%\end{array}$ & $\begin{array}{l}\text { Length } \\
\text { cm }\end{array}$ & $\begin{array}{l}\text { Mature leaves } \\
\text { no. }\end{array}$ \\
\hline 0 & $20.9 \pm 2.7 \mathrm{a}^{1}$ & $17 \pm 1.0 \mathrm{a}^{1}$ \\
50 & $22.2 \pm 3.4 \mathrm{a}$ & $15 \pm 1.3 \mathrm{a}$ \\
75 & $22.3 \pm 2.3 \mathrm{a}$ & $15 \pm 1.1 \mathrm{a}$ \\
p-value & 0.9238 & 0.3593 \\
\hline
\end{tabular}

${ }^{1}$ Averages followed by equal letters within a column do not differ statistically according to Tukey's comparison test $(\mathrm{p}=0.05)$.

Regarding the FST effect on LA/F ratio, significant differences were observed between treatments at the day of the harvest $(\mathrm{p} \leq 0.05$; Fig. 2 ). Branches with 50 and $75 \%$ FST showed an $\mathrm{LA} / \mathrm{F}$ ratio significantly higher $(1149.8 \pm 4.0$ $\mathrm{cm}^{2} \mathrm{LA} /$ fruit and $1373.9 \pm 6.4 \mathrm{~cm}^{2} \mathrm{LA} /$ fruit, respectively) than those without FST (610.6 \pm $4.1 \mathrm{~cm}^{2} \mathrm{LA} /$ fruit). For all FST levels, treatments exceeded from early season (approximately 15 DAFB) the optimal value of about $240 \mathrm{~cm}^{2} \mathrm{LA} /$ fruit suggested by Whiting and Lang (2004) and Whiting (2005) to obtain good quality fruit.

Since around 15 DAFB, the supply of photoassimilates was ensured for fruit in all the treatments. Nevertheless, regardless of this higher availability of resources, branches with 50 and $75 \%$ FST did not develop higher quality fruit than branches without FST. It seems that in the combination evaluated, photoassimilates for fruit growth were available up to a point, and beyond this there was no response in quality. This could be the result of a limitation imposed by the sink (Layne and Flore, 1985). On the other hand, the photoassimilates that were not partitioned to fruit could have been redirected to other alternative sinks such as roots, radial growth and shoot elongation. This was evident in the LA increase recorded in spurs and shoots both in the treatments T1 and T2. However, it was not observed in terms of increased shoot length. Regarding the other alternative sinks, their demand for photoassimilates was not evaluated in this study.

According to our results, FST intensity did not affect fruit quality of sweet cherry in the combination 'Lapins'/'Mazzard F-12/1'. Although the LA was sufficient for achieving quality fruit, its augmentation did not result in higher fruit size or TSSC. Therefore, the cultivar/rootstock combination studied prioritizes fruit development only up to a point, possibly due to a sink limitation or photoassimilate partitioning towards alternative sinks. Leaves were one of the alternative sinks, as the branches with 50\% FST compensated their LA development through an increase in leaf size in FSs, NFSs and UCSSs.

Our results argue against including FST as an agronomic management technique in sweet cherry orchards of the combination 'Lapins'/'Mazzard F-12/1 in years in which a low fruit load is expected. The year under study coincided with a low chilling accumulation that affected orchard production. This could have influenced the lack of response to the FST, although 'Lapins' cultivars are self-compatible and produce high fruit density per spur. Notwithstanding, FST might be useful for crop load regulation in years when a high fruit load has been predicted. Due to the experimental limitations of the reduced crop 
load in the year when this study was made, additional research using FST in the same cultivar/ rootstock combination is necessary to confirm the conclusions of this article.

\section{Resumen}

M. Ayala y M.P. Andrade. 2009. Efecto del raleo de dardos frutales en la calidad de la fruta y crecimiento vegetativo en cerezo dulce (Prunus avium). Cien. Inv. Agr. 36(3):443450. Huertos modernos de cerezo (Prunus avium) con variedades productivas y portainjertos desvigorizantes requieren, generalmente, regulación de carga frutal para obtener fruta de calidad exportable. El raleo de dardos frutales (RDF) ("extinción") se ha sugerido como una práctica de manejo para mejorar el balance entre crecimiento vegetativo y reproductivo. En Chile existe escasa información acerca del control de carga con RDF, por lo tanto, el objetivo de este ensayo fue evaluar el efecto del raleo manual de dardos en ramas de tres años de árboles de la combinación cultivar/portainjerto 'Lapins'/'Mazzard F-12/1'. El estudio evaluó el efecto del RDF en la calidad de la fruta y el crecimiento vegetativo de la temporada en tres niveles: 0,50 y 75\% de remoción de dardos por rama. La extinción de dardos se realizó 28 días antes de plena flor (23 de Agosto, 2006). El RDF no produjo efectos significativos en el tamaño, sólidos solubles totales ni peso fresco de frutos. No obstante, hubo diferencias significativas en el desarrollo foliar del brote apical, los dardos no frutales y los dardos frutales. Se observó una alta relación hoja/fruto en todos los tratamientos, en efecto, este parámetro aumentó con un 50 y $75 \%$ de RDF. El ensayo no aumentó la calidad de la fruta durante la temporada en estudio, posiblemente por una limitación sumidero en la combinación cultivar/portainjerto evaluada, o bien, la presencia de sumideros vegetativos alternativos más fuertes que la fruta. Estudios posteriores se hacen necesarios para clarificar estos puntos.

Palabras clave: Area foliar, calidad de fruta, carga frutal, crecimiento del brote, dardos, extinción, relación hoja-fruto, regulación.

\section{References}

Ayala, M. 2004. Carbon partitioning in sweet cherry (Prunus avium L.) on dwarfing precocious rootstocks during fruit development. Ph.D. Thesis, Michigan State University, East Lansing, USA. $254 \mathrm{pp}$.

Ayala, M. 2008. Los retos de los portainjertos. Agronomía y Forestal UC (Chile) 34:12-16.

Baysdorfer, C., and J.A. Bassham. 1985. Photosynthate supply and utilization in alfalfa. A developmental shift from source to a sink limitation of photosynthesis. J. Plant Physiol. 77:313-317.

Claverie, J., and J. Joublan. 2004. El Cerezo, Guía Técnica. Fundación para la Innovación Agraria. Chillán, Chile. 336 pp.

Claverie, J., and P.E. Lauri. 2005a. Extinction training of sweet cherries in France - appraisal after six years. J. Amer. Soc. Hort. Sci. 667:367-372.

Claverie, J., and P.E. Lauri. 2005b. Sweet cherry training to improve fruit size and quality - an overview of some recent concepts and practical aspects. J. Amer. Soc. Hort. Sci. 667:361-366.

Guerendiain, F. 2006. Labores culturales en Cerezo. Cartilla informativa. EEA Santa Cruz AER Los Antiguos, Argentina. Cooperativa Agrofutícola "El Oasis" Limitada.

www.inta.gov.ar/santacruz/info/documentos/agri/ fruti/Labores\%20Culturales\%20en\%20Cerezos. pdf. (Accessed: December, 2006).

Lang, G.A. 1998. High density orchards and intensive crop regulation. Good Fruit Grower 49:4547.

Layne, D.R., and J.A. Flore. 1985. End-product inhibition of photosyntesis in Prunus cerasus L. in response to whole-plant source-sink manipulation. J. Amer. Soc. Hort. Sci. 120:583-599.

Lemus, G. 2005. El Cultivo del Cerezo. Boletín INIA $\mathrm{N}^{\mathrm{o}}$ 133. Instituto de Investigaciones Agropecuarias. Santiago, Chile. 256 pp.

Long, L. 2002. Spur Thinning can increase fruit size. 
Oregon State University Extension Service. Hort. Update 15:1-6.

Podestá, L., M. Ojer, J. Claverie, and C. Arjona. 2005. Regulación de la carga frutal en cerezos cultivar Lapins. Libro de Resúmenes, XII Congreso Latinoamericano, XXVIII Congreso Argentino de Horticultura. 45 pp.

Roper, T., and W. Loescher. 1987. Relationships between leaf area per fruit and fruit quality in 'Bing' sweet cherry. J. Amer. Soc. Hort. Sci. 22:1273-1276.

Wedeles, P. 2006. La importancia de la Regulación de la Carga Frutal en Combinaciones Enanizantes de Cerezo dulce (Prunus avium L.). Proyecto de Título para optar al Título de Ingeniero Agrónomo. Pontificia Universidad Católica de Chile, Santiago, Chile.
Whiting, M.D. 2005. Physiologycal Principles for Growing Premium Fruit. Pages 57-64. In: Producing Premium Cherries. Pacific Northwest Fruit School Cherry Short Course Proceedings. Chapter 9, Washington, USA.

Whiting, M.D., and G.A. Lang. 2004. 'Bing' sweet cherry on the dwarfing rootstock 'Gisela 5': Thinning affects tree growth and fruit yield and quality but not net $\mathrm{CO}_{2}$ exchange. J. Amer. Soc. Hort. Sci. 129: 407-415.

Whiting, M.D., and D. Ophardt. 2005. Comparing novel sweet cherry crop load management strategies. J. Amer. Soc. Hort. Sci. 40:1271-1275.

Whiting, M.D., Lang, G. A., and D. Ophardt. 2005. Rootstock and training system affect sweet cherry growth, yield and fruit quality. J. Amer. Soc. Hort. Sci. 40:582-586. 